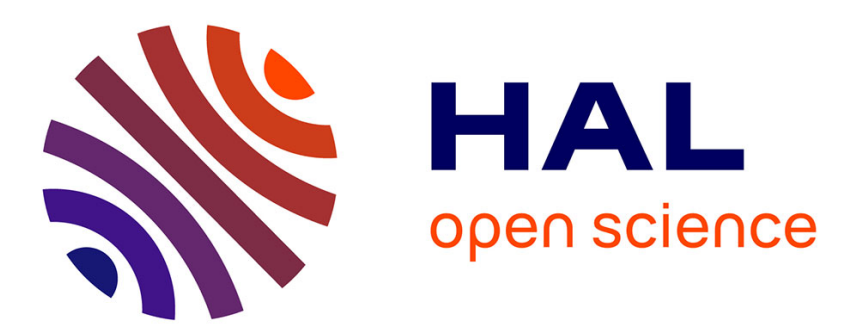

\title{
Effect of wetting-drying cycles on mortar samples affected by DEF
}

Ali-Nordine Leklou, Jean-Emmanuel Aubert, Gilles Escadeillas

\section{To cite this version:}

Ali-Nordine Leklou, Jean-Emmanuel Aubert, Gilles Escadeillas. Effect of wetting-drying cycles on mortar samples affected by DEF. European Journal of Environmental and Civil Engineering, 2012, 16 (5), pp.582-588. 10.1080/19648189.2012.668017 . hal-01006778

\section{HAL Id: hal-01006778 https://hal.science/hal-01006778}

Submitted on 16 Mar 2018

HAL is a multi-disciplinary open access archive for the deposit and dissemination of scientific research documents, whether they are published or not. The documents may come from teaching and research institutions in France or abroad, or from public or private research centers.
L'archive ouverte pluridisciplinaire HAL, est destinée au dépôt et à la diffusion de documents scientifiques de niveau recherche, publiés ou non, émanant des établissements d'enseignement et de recherche français ou étrangers, des laboratoires publics ou privés. 


\title{
Effect of wetting-drying cycles on mortar samples affected by DEF
}

\author{
N. Leklou ${ }^{\mathrm{a} *}$, J.-E. Aubert ${ }^{\mathrm{b}}$ and G. Escadeillas ${ }^{\mathrm{b}}$ \\ ${ }^{a}$ LUNAM Université, Université de Nantes - POLYTECH NANTES; GeM, UMR CNRS 6183 - \\ Research Institute on Civil Engineering and Mechanics, IUT Saint-Nazaire, Saint-Nazaire \\ CedexFrance; ${ }^{b}$ Université de Toulouse;UPS, INSA;LMDC (Laboratoire Matériaux et \\ Durabilité des Constructions), Toulouse Cedex, France
}

This article, which deals with the effect of wetting-drying (W-D) cycles on materials affected by delayed ettringite formation (DEF), has two main objectives. The first is to observe whether W-D cycles pre-damage samples, by using the replica technique. Scanning electron microscopy (SEM) observations of replicas show that W-D cycles lead to microcracks in the samples. The second objective of the study is to observe whether the cycles are necessary for development of DEF or if they only accelerate DEF. A study of the expansion of the samples shows that cycles accelerate the appearance of expansion but they are not a prerequisite for triggering DEF.

Cet article, qui porte sur l'effet des cycles d'humidification-séchage des matériaux atteints de DEF, a deux objectifs principaux. Le premier objectif est d'observer par l'utilisation de la technique de la réplique, si les cycles d'humidification-séchage pré-endommageaient les échantillons. Les résultats obtenus par le suivi des répliques ont permis de conclure que les cycles pré-endommagent les éprouvettes. Le second objectif de cette étude, est d'observer si les cycles sont nécessaires au développement de la DEF ou s'ils ne font qu'accélérer la DEF. Le suivi des expansions a montré que les cycles permettent d'accélérer l'apparition des expansions, mais qu'ils ne sont pas un préalable nécessaire pour le déclenchement de la DEF.

Keywords: wetting-drying cycles; microcracks; scanning electron microscopy (SEM); replica; delayed ettringite formation (DEF); expansion

Mots-Clés: cycles d'humidification-séchage; microfissuration; microscope électronique à balayage (MEB); réplique; formation d'ettringite différée (DEF); expansions

\section{Introduction}

Delayed ettringite formation (DEF) by heat-induced internal sulphate attack of cementbased materials is the latest discovery concerning a disorder that causes significant disturbances in concrete structures and has become a major problem in terms of durability of structures. In more than 20 years of research, numerous laboratory experiments have been carried out to study this pathology. The main conclusions of this research were summarised at the RILEM workshop on Internal Sulfate Attack and Delayed Ettringite Formation (Skalny, 2002).

Based on the conclusions of this workshop and other references (Collepardi, 2003; Diamond, 1996; Taylor, Famy, \& Scrivener, 2001; Skalny, 2002), it is possible to summarise the conditions necessary for the appearance of DEF as:

*Corresponding author. Email: nordine.leklou@univ-nantes.fr 
- an excessive rise of temperature during the casting of the concrete, related to the high heat of hydration of large masses of concrete or to the steam curing of concrete, especially in the case of precast products. This high temperature $\left(>60-70^{\circ}\right.$ C) inhibits the formation of non-expansive preliminary ettringite;

- the presence of sulphates, essentially coming from the cement (added as a set retarder or present inside the particles of clinker) and, to a lesser extent, from the aggregate or the mixing water. These sulphates can react with the aluminates of the cement in presence of water to form delayed expansive ettringite;

- a moist environment: all the field disorders have appeared in areas exposed to water (e.g. bridges, dams and rail ties).

The result of this pathology is an expansion caused by delayed ettingite formation without an external sulphate supply. As for the alkali-aggregate reaction, the appearance of the disorder usually occurs after several decades, which further complicates its study. Numerous factors are important or even indispensable, such as a preliminary microcracking (Collepardi, 2003; Fu \& Beaudoin, 1996), wetting-drying (W-D) cycles (Fu \& Beaudoin, 1996; Grabowski, Czarnecki, Gillott, Duggan, \& Scott, 1992; Pavoine, Divet, \& Fenouillet, 2006) and the alkali content of the cement (Aubert, Escadeillas, \& Leklou, 2009; Damidot \& Glasser, 1993; Divet \& Randriambololona, 1998; Escadeillas, Aubert, Segerer, \& Prince, 2007; Glasser, 1996). Many years of research on the subject has helped to increase awareness of the pathology and, in particular, the influence of the different parameters.

Currently, many studies are conducted on concrete that has undergone W-D cycles (Brunetaud, Linder, Divet, Duragrin, \& Damidot, 2007; Pavoine et al., 2006) after heat treatment but the effects of these cycles are still not well understood. Other authors (Collepardi, 1999; Fu, Xie, Gu, \& Beaudoin 1994) also indicate that preliminary microcracking of samples is a prerequisite to DEF. The study presented in this article has two main objectives. The first is to observe whether W-D cycles predamage samples. The second is to answer the two important questions of whether preliminary microcracking is necessary for the appearance of DEF and whether preliminary microcracking has an effect on the kinetics of the development of this pathology.

To achieve these aims, the expansion of two mortars (one subjected to W-D cycles and the other not) was studied and their microcracking was observed with SEM using the replica technique.

\section{Experiments}

\subsection{Materials}

An ordinary portland cement was used in this study (CEM I 52.5 R type according to NF EN 197-1, standard comparable to ASTM Type III cement). The chemical analyses of this cement are given in Table 1 together with phase compositions from Bogue calculation. To accelerate and amplify the appearance of the phenomenon, $3.1 \%$ (by weight of cement) of $\mathrm{Na}_{2} \mathrm{SO}_{4}$ was added to the cement (Escadeillas et al., 2007; Leklou, Aubert, \& Escadeillas, 2009). The sodium sulphate was a pure commercial product and its fineness was comparable to that of the cement. The siliceous aggregate was a French sand meeting standard NF EN 196-1. This aggregate is classified as non-reactive with respect to alkali-silica reaction by NF-P 18-590.

The siliceous nature of the aggregate was chosen because it leads to faster expansion than with limestone sand. 
Table 1. Chemical and mineralogical composition of the cement $(\% \mathrm{w} / \mathrm{w})$.

\begin{tabular}{lc}
$\mathrm{Cement}$ & Content (\%) \\
\hline $\mathrm{SiO}_{2}$ & 19.1 \\
$\mathrm{Al}_{2} \mathrm{O}_{3}$ & 3.8 \\
$\mathrm{Fe}_{2} \mathrm{O}_{3}$ & 3.1 \\
$\mathrm{CaO}$ & 60.6 \\
$\mathrm{MgO}$ & 1.7 \\
$\mathrm{SO}_{3}$ & 3.1 \\
$\mathrm{~K}_{2} \mathrm{O}$ & 1.1 \\
$\mathrm{Na}_{2} \mathrm{O}$ & 0.5 \\
$\mathrm{Equivalent}_{\mathrm{Na}} \mathrm{O}$ & 1.2 \\
$\mathrm{C}_{3} \mathrm{~S}$ Bogue & 53.1 \\
$\mathrm{C}_{2} \mathrm{~S}$ Bogue & 15.3 \\
$\mathrm{C}_{3} \mathrm{~A}$ Bogue & 6.9 \\
$\mathrm{C}_{4}$ AF Bogue & 9.3 \\
\hline
\end{tabular}

The mortar (3:1:0.5 sand: cement: water) was prepared according to standard NF EN 196-1. Mortar prisms were cast in $40 \times 40 \times 160 \mathrm{~mm}$ metallic moulds. The mortar samples were cured directly in their moulds, equipped with embedded length measurement studs. During the thermal treatment, the moulds were covered with a metal plate to limit water exchange.

\subsection{Procedures}

\subsubsection{Heat treatment}

As shown in the literature, the curing temperature plays a key role in the development of delayed ettringite. After casting, the mortar and concrete specimens were cured according to the heat treatment of Figure 1, which followed a cycle divided into four different phases:

- Phase no. 1: pre-cure at $20^{\circ} \mathrm{C}$ for $1 \mathrm{~h}$.

- Phase no. 2: temperature rise at $20^{\circ} \mathrm{C} / \mathrm{h}$.

- Phase no. 3: temperature plateau $80^{\circ} \mathrm{C}$ for $10 \mathrm{~h}$.

- Phase no. 4: natural return to ambient temperature (about $20^{\circ} \mathrm{C}$ ).

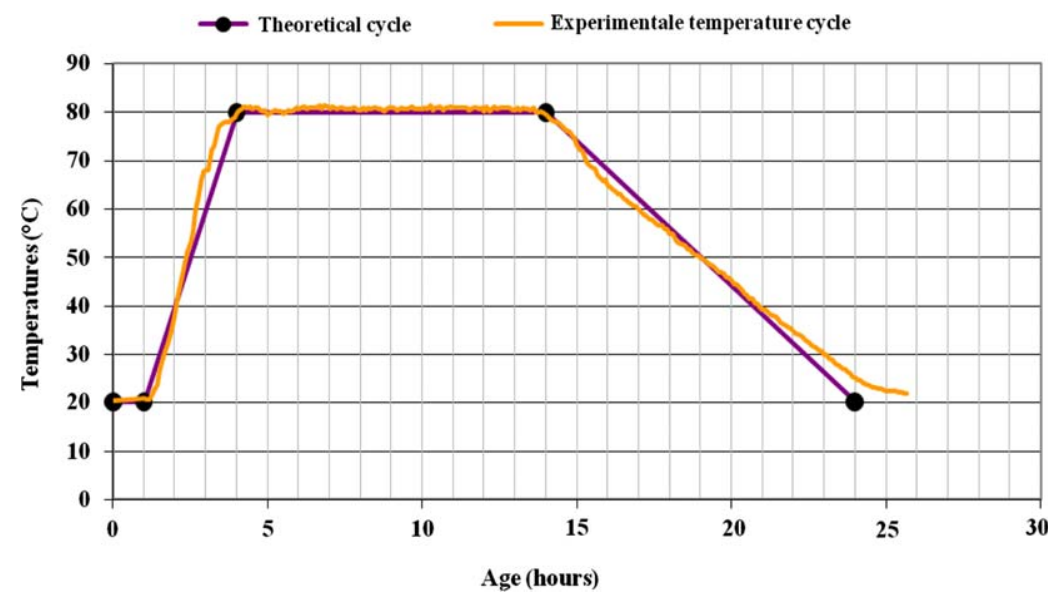

Figure 1. Temperature cycle imposed on the heat cured specimens. 
This heat treatment is representative of the treatments used in some precast industries.

The specimens were placed in a drying oven fitted with a temperature controller. Thermocouples were placed in the control specimen to verify the temperatures reached during the treatment. During heat treatment, the specimens were covered by a metal plate to prevent excessive water loss and thus keep the relative humidity near saturation (90-100\%). After cooling, the prisms were demoulded and stored in water at $20^{\circ} \mathrm{C}$.

\subsubsection{Test procedures}

Dimensional measurement. Expansion measurements were performed with an extensometer having an accuracy of $1 \mu \mathrm{m}$. The frequency of these measurements was high during the period of maximum speed of expansion (weekly) and decreased when the speed of expansion was low (monthly). Each point on the graph is derived from the average calculated from the expansions of three specimens. The measurements on the specimens subjected to the wetting-drying cycles were carried out after each immersion period and after each drying period.

Microscopic observations using replica technique. For scanning electron microscopy (SEM) observations, a JEOL 6380 LV equipped with a backscattered electron (BSE) detector was used. The microscopic examinations were carried out using the replica technique as already used for the visualisation of microcracks by Ollivier (1985) and Leklou et al. (2009). LMDC developed this technique in the 1980s and used it, in particular, for monitoring the evolution of cracking in concrete. It has the advantage of not introducing artefacts in the observation of microcracks (Leklou et al., 2009). To prepare a replica, methyl acetate was pulverised on the surface of the sample and a film of bioden (celluloseacetyl) was applied immediately to the polished surface. Once the solvent had evaporated ( 2 minutes), the film was delicately removed and pasted on a brass support. The metallised replica was then observed with SEM.

Wetting-drying cycles. For this part of the work, 14 days after heat treatment and demoulding, half the specimens were stored in water at $20^{\circ} \mathrm{C}$ while the other half underwent 10 wetting-drying cycles $\left(5\right.$ days in water at $20^{\circ} \mathrm{C}$ followed by 2 days in a drying oven at $50^{\circ} \mathrm{C}$ ). In both cases, the storage water was not renewed during the tests.

\section{Results and discussion}

\subsection{Effects of wetting-drying cycles on microstructure of the samples}

The SEM observation of replicas taken before each cycle (Figure 2) allowed the spread of the first cracks caused by W-D cycles to be located and tracked.

The replicas made on the surface of the mortar sample (Figure 2) show that W-D cycles damaged the specimens by creating microcracks:

- in the initial state (Figure 2a), no cracks are visible in the cement paste and no damage is visible in the paste-aggregate interfaces. Thus, indirectly, this observation shows that the initial heat treatment, however severe, does not cause damage, while the literature often indicates that the subsequent cooling heat treatment was the source of cracking;

- after five W-D cycles (Figure 2b), a small crack is visible in the cement paste and is prolonged in the paste-aggregate interfaces;

- after $10 \mathrm{~W}$-D cycles (Figure 2c), this first crack has opened considerably and a second, perpendicular, crack has appeared. 
(a)

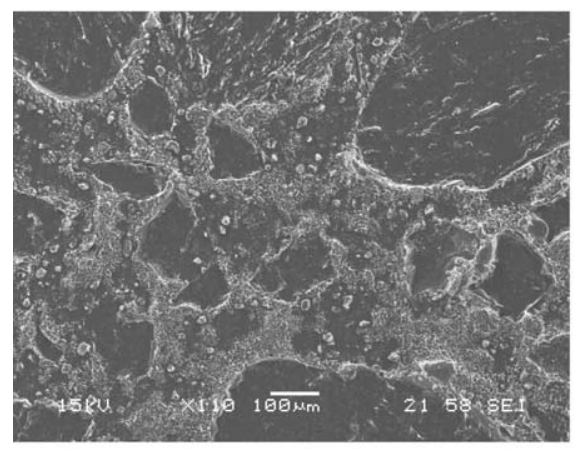

(b)

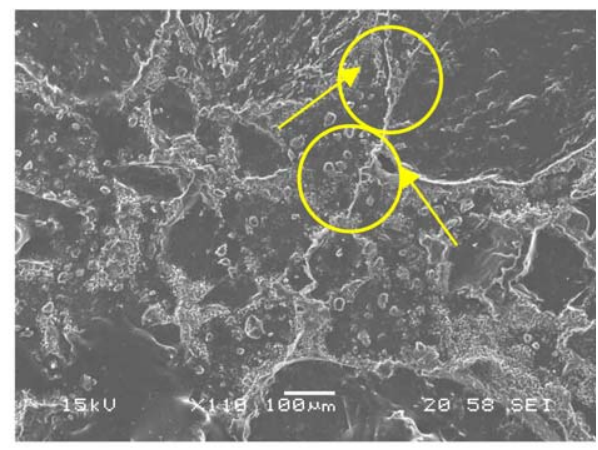

(c)

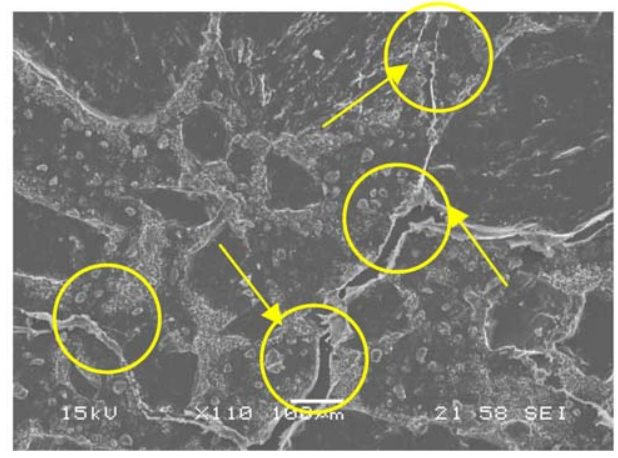

Figure 2. Replicas of the same polished face of a specimen of mortar: (a) initial state; (b) state after five W-D cycles; (c) state after 10 W-D cycles (high-vacuum $-\times 110-$ mode SEI).

In order to observe if the W-D cycles had a significant effect on the kinetics of expansion of mortar specimens, the variations of expansion caused by the DEF were measured.

\subsection{Impact on the kinetics of swelling}

The length variations of the mortars subjected to the W-D cycles are presented in Figure 3 and compared with the length variations of specimens continuously conserved in water at $20^{\circ} \mathrm{C}$.

The results presented in Figure 3 show that the preliminary microcracking induced by the W-D cycles significantly accelerates the appearance of the expansion. This result is in accordance with those obtained by other researchers (Pavoine et al., 2006; Petrov \& Tagnit-Hamou, 2004). Several possible explanations can be put forward for this phenomenon.

First, the microcracking induced by the W-D cycles weakens the cement paste. According to the mechanism proposed by Brunetaud et al. (2007), the uniform expansion of the cement paste due to DEF (latent period) induces pressures in the material that generate or do not generate cracks according to the resistance of the material. The development of cracks accelerates the expansion of the material and corresponds to the second phase of the mechanism (acceleration of expansion). So, according to this mechanism, the more resistant the cement paste is, the longer it takes to pass on to the phase during which high expansion will occur (and conversely). 


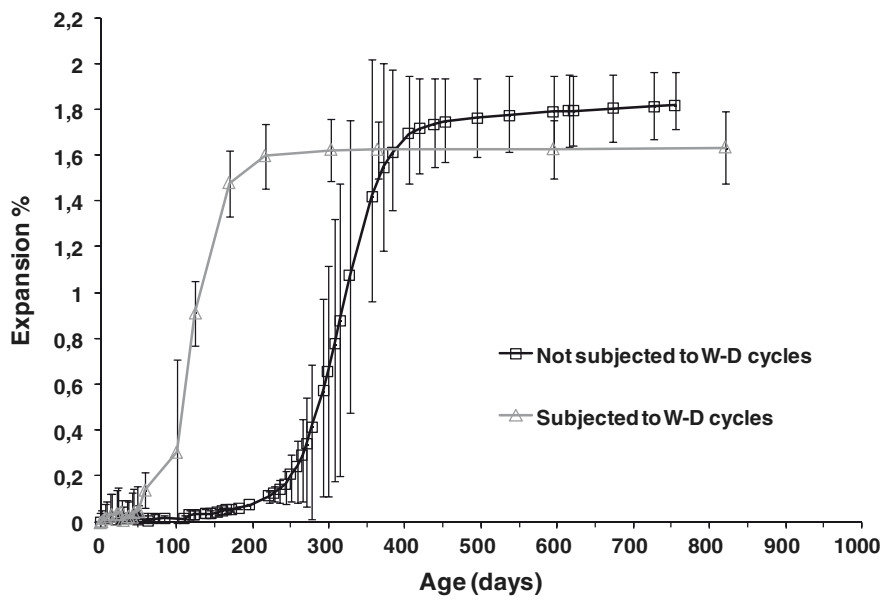

Figure 3. Length variations of the mortars subjected or not subjected to the W-D cycles.

Secondly, the microcracking induced by the W-D cycles leads to an increase in the porosity, the consequence of which is an increase in hydrous and ionic transfers. These ionic transfers can play different roles in the appearance and development of DEF. First, the increase of the mobility of aluminate and sulphate ions contained in the material supports the formation of ettringite. Secondly, the increase in ionic transfers accelerates the leaching of alkalis, which modifies the chemical balance of the pore solution by decreasing the concentration of alkalis. This decrease of alkalis in the pore solution (and consequently its $\mathrm{pH}$ ) supports the desorption of sulphates from the $\mathrm{CSH}$ as shown by Divet and Randriambololona (1998). This is favourable for the formation of ettringite and could explain why the expansion is accelerated by W-D cycles.

Finally, the results presented in Figure 3 confirm that the cracking of the samples is not a prerequisite for DEF since it also develops (but later) in mortars continuously conserved in water and, also, not initially microcracked. These observations confirm those published previously by Escadeillas et al. (2007).

\section{Conclusions}

The study of the effects of wetting-drying cycles on the appearance of DEF makes it possible to draw the following conclusions:

- Firstly, as expected, although this has never been clearly demonstrated, the succession of W-D cycles results in damage to the material by creating microcracks in the specimen. The replica technique showed that five cycles of seven days were enough to initiate microcracks at the specimen surface and the continuation of these cycles led to the propagation of these cracks.

- The study of the expansions measured on the specimens affected by DEF confirms that, under severe experimental conditions (high curing temperature, high sulphate, alkali and $\mathrm{C} 3 \mathrm{~A}$ contents), microcracking of the samples is not a prerequisite for DEF since it also develops (but later) in mortars not subjected to the W-D cycles. These observations confirm those published previously by Escadeillas et al. (2007). 
- Finally, as had been shown previously by other researchers (Pavoine et al., 2006; Petrov et al., 2004), the W-D cycles greatly accelerate the appearance of expansion. Two hypotheses can be found to explain this acceleration: that the microcracking induced by the W-D cycles weakens the cement paste; and that it increases the ionic and hydrous transfers. These are only speculations and need to be confirmed by experimental results. Further investigations should be carried out in order to verify these hypotheses, e.g. measurements of the pore solution or of the storage water during the conservation of the samples affected by DEF.

\section{References}

Aubert, J.E., Escadeillas, G., \& Leklou, N. (2009). Expansion of five years old mortars attributable to DEF: relevance of the laboratory studies on DEF? Construction and Building Materials, 23, 3583-3585.

Brunetaud, X., Linder, R., Divet, L., Duragrin, D., \& Damidot, D. (2007). Effect of curing conditions and concrete mix design on the expansion generated by delayed ettringite formation. Materials and Structures, 40, 567-578.

Collepardi, M. (1999). Damage by delayed ettringite formation. Concrete International, 1999, 69-74.

Collepardi, M. (2003). A state-of-the-art review on delayed ettringite attack on concrete. Cement and Concrete Composites, 25, 401-407.

Damidot, D., \& Glasser, F.P. (1993). Thermodynamic investigation of the CaO-Al2O3-CaSO4$\mathrm{H} 2 \mathrm{O}$ system at $25^{\circ} \mathrm{C}$ and the influence of $\mathrm{Na} 2 \mathrm{O}$. Cement and Concrete Research, 23, 221-238

Diamond, S. (1996). Delayed ettringite formation - processes and problems. Cement and Concrete Composite, 18, 205-215.

Divet, L., \& Randriambololona, R. (1998). Delayed ettringite formation: the effect of temperature and basicity on the interaction of sulphate and C-S-H phase. Cement and Concrete Research, $28,357-363$.

Escadeillas, G., Aubert, J.-E., Segerer, M., \& Prince, W. (2007). Some factors affecting delayed ettringite formation in heat-cured mortars. Cement and Concrete Research, 37, 1445-1452.

$\mathrm{Fu}$, Y., \& Beaudoin, J.J. (1996). Microcracking as a precursor to delayed ettringite formation in cement systems. Cement and Concrete Research, 26, 1493-1498.

Fu, Y., Xie, P., Gu, P., \& Beaudoin, J.J. (1994). Significance of pre-existing cracks on nucleation of secondary ettringite in steam cured cement paste. Cement and Concrete Research, 24, $1015-1024$.

Glasser, F.P. (1996). The role of sulfate mineralogy and cure temperature in delayed ettringite formation. Cement and Concrete Composites, 19, 187-193.

Grabowski, E., Czarnecki, B., Gillott, J.E., Duggan, C.R., \& Scott, J.F. (1992). Rapid test of concrete expansivity due to internal sulfate attack. ACI Materials Journal, 89, 469-480.

Leklou, N., Aubert, J.E., \& Escadeillas, G. (2009). Microscopic observations of samples affected by the delayed ettringite formation (DEF). Materials and Structures, 42, 1369-1378.

Ollivier, J.P. (1985). A non destructive procedure to observe the microcracks of concrete by scanning electron microscopy. Cement and Concrete Research, 15, 1055-1060.

Pavoine, A., Divet, L., \& Fenouillet, S. (2006). A concrete performance test for delayed ettringite formation: Part I optimization. Cement and Concrete Research, 36, 2138-2143.

Petrov, N., \& Tagnit-Hamou, A. (2004). Is microcracking really a precursor to delayed ettringite formation and consequent expansion? ACI Materials Journal, 101, 442-447.

Skalny, J. (2002). Internal sulfate attack - points of agreement and disagreement. In Workshop on Internal Sulfate Attack and Delayed Ettringite Formation, RILEM proceedings PRO 35.

Taylor, H.-F.-W., Famy, C., \& Scrivener, K.-L. (2001). Delayed ettringite formation. Cement and Concrete Research, 31, 683-693. 